\title{
Kuluçkalık yumurtaların değişik oranlarda propolis ile dezenfekte edilmesinin kuluçka sonuçları ve toplam bakteri sayısı üzerine etkisi*
}

\author{
İsmail TÜRKER ${ }^{1}$, Tolga İBAS², Ömer ERTÜRK ${ }^{3}$ \\ 1Bozok Üniversitesi Ziraat Fakültesi Zootekni Bölümü, YOZGAT \\ ${ }^{2}$ Giresun İl Gıda Tarım ve Hayvancılık Müdürlügü̆, GİRESUN \\ ${ }^{3}$ Ordu Üniversitesi Fen-Edebiyat Fakültesi Moleküler Biyoloji ve Genetik Bölümü, ORDU \\ *Yüksek Lisans tezinden özetlenmiştir. Ordu Üniversitesi BAP Birimi BY-1702 nolu proje ile desteklenmiştir.
}

Alınış tarihi: 11 Ocak 2018, Kabul tarihi: 05 Mart 2018

Sorumlu yazar: İsmail TÜRKER, e-posta:iturker37@hotmail.com

\section{Öz}

Araştırma, kuluçkalık yumurtaların değişik oranlarda propolis ile dezenfekte edilmesinin kuluçka sonuçları ve toplam bakteri sayıları üzerine etkisini belirlemek amacıyla yürütülmüștür. $\mathrm{Bu}$ amaçla Tavukçuluk Araştırma Enstitüsü'nde bulunan Atak-S ticari yumurtaci tavuk ebeveynlerinden elde edilen kuluçkalık yumurtalar, kontrol, \% 3 propolis, $\% 6$ propolis ve \% 9 propolis olmak üzere 4 gruba ayrılmıştır. Araştırmada her bir grupta 480 adet olmak üzere toplam 1920 adet yumurta kullanılmıştır. Dezenfektanlar yumurtalara uygulamadan önce, uygulandıktan sonra ve kuluçkanın 18. gününde alınan numunelerde toplam bakteri sayımı yapılmıştır. Araştırmada, kuluçka randımanı, çıkış gücü, malformasyon oranı, malpozisyon oranı, civciv kalitesi, ıskarta civciv oranı, erken, orta ve geç dönem embriyo ölüm oranları ile toplam bakteri sayıları üzerinde durulmuştur. Üzerinde durulan kuluçka özelliklerinden çıkış gücü, kuluçka randımanı, malpozisyon oranı, erken ve geç dönem embriyo ölüm oranları bakımından gruplar arasında önemli farklılı bulunurken, ıskarta civciv oranı, malformasyon oranı, civciv kalitesi, orta dönem embriyo ölüm oranı ve toplam bakteri sayısı bakımından gruplar arasında farklılık bulunmadığı tespit edilmiştir. Araştırmada kullanılan dezenfektanlardan \% 3 propolis grubunda yer alan yumurtaların kuluçka sonuçlarının diğer gruplardan daha iyi olduğu ancak bu grubun antibakteriyel etkisinin diğerlerine göre daha kısa olduğu sonucuna varılmıştır.

Anahtar kelimeler: Kuluçka, propolis, dezenfektan, kuluçka sonuçları, toplam bakteri

Effect of disinfection of hatching eggs with propolis at different ratio on hatching results and total number of bacteria

\begin{abstract}
This study was conducted to determine the influence of disinfected with propolis at different rates on hatching results and total bacteria count. For this purpose, hatching eggs were obtained from parents of Atak-S commercial layer at the Poultry Research Institute. The hatching eggs were divided into 4 groups, control, $3 \%$ propolis, $6 \%$ propolis and $9 \%$ propolis. A total of 1920 eggs, with 480 in each of the groups, were used in the study. Total bacterial counts were made before applying the disinfectants, after applying the disinfectants and 18 days of incubation. In the study, hatchability, hatchability of fertile eggs, malformation rate, malposition rate, chick quality, discard chick rate, early, middle and late embryo mortality rates and total bacterial counts were examined. Significant differences were found among the groups in terms of hatchability, hatchability of fertile eggs, malposition rate, early and late embryo mortality. There was no difference between the groups in terms of discard chick rate,
\end{abstract}


malformation rate, chick quality, medium embryo mortality and total bacteria count. It was concluded that the eggs incubated in 3\% propolis group had better hatching results than the other groups but the antibacterial effect of this group was shorter than the other groups.

Key words: Hatchery, propolis, disinfectant, hatching results, total bacteria

\section{Giriş}

Kanatlıların yaşam döngüsü, kuluçkalık yumurta üretimi ve bu yumurtalardan kuluçka işlemi ile civciv çıkarılmasından ibarettir. Memeli hayvanlar ile kıyaslandığında embriyo gelişiminin büyük bölümü yumurtlamadan sonra diş ortamda tamamlanır. Kuluçka olarak da tanımlanan bu dönem yapay ya da doğal yöntemler ile sağlanır. Günümüzde kanatlı sektöründe kuluçka denildiğinde yapay kuluçka akla gelmektedir (Elibol, 2014). Kuluçka kanatlı üretim döngüsünün en önemli bölümlerindendir. Kuluçka esnasında meydana gelebilecek sorunlar üretimin henüz başında zaman ve para kaybına yol açabilir. Çadırcı, (2009), kanatlı hayvan endüstrisinde kuluçkalık yumurtaların mikrobik kontaminasyonundan kaynaklanan maddi kayıpların milyonlarca Euro'ya ulaştığını bildirmiştir. Avrupa Birliği ülkelerinde 2016 yılında üretilen kuluçkalık yumurta sayısı 13.5 milyar civarındadır. Türkiye'de ise 2016 yılında sadece yumurtacı tavuk civcivi elde etmek amacıyla kuluçka işlemine tabi tutulan yumurta sayısı yaklaşık 178 milyon olarak gerçekleşmiştir (Anonim, 2017).

Elibol, (2014), kanatlı kuluçkahanelerine farklı damızlık işletmelerden yumurta gelmesi ve kuluçka çıkan civcivlerin de değişik işletmelere gönderilmesini olağan bir durum olarak nitelemektedir. Yumurta ve civcivlerin kuluçka öncesi ve sonrasında kuluçkahaneler ve çiftlikler arasındaki transferleri hastalıkların yayılmasının önlenmesi açısından kuluçkalık yumurtaların hijyeni konusunu önemli kılmaktadır.

Kuluçka işletmelerinin karlı olabilmesi için başarılı ve ekonomik bir dezenfeksiyon yöntemi uygulamaları gereklidir. Kuluçkalık yumurtalarda kullanılacak olan dezenfektan maddeler, mikroorganizmalar üzerine yüksek etkinlikte olmal,, insan ve hayvan sağlığına zarar vermemeli, suda çözünür olmalı, temini kolay ve ekonomik olmalıdır (Elibol, 2014).
Kuluçkahane ve kuluçkalık yumurtaların dezenfeksiyonunda kullanılan başlıca yöntemler; fumigasyon, sprey uygulama, yumurtaların dezenfektanlara daldırılması ve ultraviyole ışık uygulamalarıdır. Dezenfeksiyon işlemi için formaldehit, sodyum hidroksit, oksitlendirilmiş su, dörtlü amonyum bileşikleri, fenoller, antibiotik flumisol, hidrojen peroksit, timsen, poliheksametilenbiguanid hidroklorür (PHMB) içeren kimyasallar kullanılmaktadır (Baylan ve ark., 2015). HACCP standartlarına göre dezenfeksiyon mikroorganizmaların \%99.99 oranında azaltılması ile mümkündür (Ledoux, 2004).

Hijyenik koşullara dikkat edilmeyen kuluçkahanelerde, özellikle E. coli, Staphylacoccus sp., Bacillus sp. ve Pseudomona sp. gibi bakterilerin yumurtalarda kontaminasyona neden olduğu bunun sonucunda da civcivlerde göbek iltihabı (omphalitis) görüldüğü bildirilmiştir (Chute ve Gershman, 1961; Ernst ve ark., 1980; Sheldon ve Ball, 1986).

Her alanda olduğu gibi dezenfektanların kullanıldığ alanlarda da insan sağlığı, çevresel kaygılar ve tüketicilerin kalıntı bırakmayan gıda talepleri nedeniyle mikrobiyal bulaşmayı kontrol etmek ve kimyasal ajanlara olan bağımlılığı azaltmak için düşük risk içeren alternatif yöntemlerle ilgili araştırmalar yapılmaktadır (Aygün ve ark., 2012). Bitkilerden elde edilen doğal biyolojik aktif bileşiklerin genelde sentetik elde edilen bileşiklerden daha az zararlı olduğu ve potansiyel hastalık kontrol ajanları açısından daha zengin bir kaynağı temsil ettiği kabul edilebilir. Doğal bitki içeriklerinden elde edilen maddeleri kullanarak patojen mikroorganizmalara karşı etkili olan bitki türleri ve bu türlerin içerdikleri etken maddelerin tespit edilmesi, dünyada üzerinde yoğun bir şekilde çalışılan alan haline gelmiştir (Dülger ve ark., 1999; Benli ve Yiğit, 2005; Toroğlu ve Çenet, 2006). Bu kapsamda antibakteriyel ve antifungal özellikleri belirlenmiş olan doğal ürünlerin yumurta dezenfeksiyonunda kullanılması önem kazanmaktadır (Baylan ve ark., 2015).

Araştırma, insan sağlığına zararlı etkisi bulunmayan ve organik yapıda olan propolisin kuluçka işlemi öncesinde yumurtaların dezenfeksiyonunda kullanma imkanlarını araştırmak üzere yürütülmüştür.

\section{Materyal ve Yöntem}

Araştırmada Atak-S ticari yumurtacl tavuk ebeveynlerinden elde edilen kuluçkalık yumurta kullanılmıştır. Yumurtalar gelişim makinelerine 
yerleştirilmeden önce makinelerin içindeki tepsi ve kasaların temizliği yapılmış, dezenfektan madde içeren solüsyon ile gelişim ve çıkış makinaları dezenfekte edilmiștir. Ardından makinelerin kapıları 24 saat açık bırakılarak kurumaları sağlanmıştır. Oda sıcaklığında saklanan kuluçkalık yumurtalar herhangi bir yıkama veya temizlik işlemine tabi tutulmamışlardır.

Araştırma, kontrol, \% 3 propolis, \% 6 propolis ve \% 9 propolis olmak üzere 4 grupta 6 tekerrürlü olarak yürütülmüștür. Her bir tekerrürde 80 adet kuluçkalık yumurta olacak şekilde toplam 1920 kuluçkalık yumurta kullanılmıştır. Kontrol grubu olarak ele alınan klorid grubu dezenfektan püskürtme yöntemi ile uygulanmış ve yumurtaların tüm yüzeyi dezenfektana maruz bırakılmıştır. Diğer dezenfektan grupları olan $\% 3$ propolis, \% 6 propolis ve \% 9 propolis çözeltilerine yumurtalar daldırma yöntemi ile dezenfekte edilmiştir. Tüm yumurta gruplarından 5'er adet yumurta numune olarak alınmış ve mikrobiyolojik analizler yapılmak için laboratuvara götürülmüştür.

Kontrol grubu dezenfektan olarak piyasada satılan klorid grubu dezenfektan kullanılmıştır. Propolis çözeltilerinin hazırlanması için gerekli propolis Ordu Arıcılık Araştırma Enstitüsünden temin edilmiştir. Etil alkol içerisinde çözdürülen propolis, \%3 propolis (3 g. propolis $+997 \mathrm{ml}$ etil alkol), \%6 propolis (6 g. propolis+994 ml etil alkol) ve $\% 9$ propolis (9 g. propolis+991 ml etil alkol) içeren çözeltiler şeklinde hazırlanmıştır.

Dezenfeksiyon işleminden sonra yumurtalar $24^{\circ} \mathrm{C}$ sıcaklık ve \% 75 nem içeren dinlenme odasında 12 saat süreyle ön isıtmaya tabi tutulmuştur. Daha sonra $37.7^{\circ} \mathrm{C}$ sıcaklık ve \% 60 nem içeren gelişim makinesine nakledilmiştir. Burada 18 gün bekletildikten sonra yumurtalara lamba ile döllülük kontrolü yapılmıştır. Döllülük kontrolü yapılan yumurtalar $37-37.2^{\circ} \mathrm{C}$ sicaklık, \% 70 nispi nem içeren çıkış makinelerine nakledilmiştir. Yumurtalardan her gruptan 5'er numune alınarak mikrobiyolojik analiz yapılması için laboratuvara götürülmüştür. Daha sonra civcivlerin çıkışı yapılmış ve araştırmada incelenen özellikler aşağıda belirtilen formüller yardımıyla hesaplanmıştır:

Araştırma süresince aşağıda belirtilen kuluçka özellikleri belirlenmiştir.

-Döllülük oranı : (Döllü yumurta sayısı/Kuluçkaya konulan yumurta sayısı)*100 formülü,
-Kuluçka randımanı: (Kuluçkadan çıkan canlı civciv sayısı / Kuluçkaya konan toplam yumurta sayısı)*100 formülü,

-Çıkış gücü: (Kuluçkadan çıkan canlı civciv sayısı / Kuluçkaya konan döllü yumurta sayısı)*100 formülü, -Erken dönem embriyo ölümleri: (kuluçkanın 0-6 günleri arasında ölen embriyo sayısı / Döllü yumurta sayısı)*100 formülü,

-Orta dönem embriyo ölümleri: (Kuluçkanın 7-18 günleri arasında ölen embriyo sayısı / Döllü yumurta sayısı)*100 formülü,

-Geç dönem (kabuk altı) embriyo ölümleri: (Kuluçkanın 19-21 günleri arasında ölen embriyo sayısı / Döllü yumurta sayısı)*100 formülü,

-Iskarta civciv oranı: Kuluçkadan çıkan ıskarta civciv sayısı / Kuluçkaya konulan yumurta sayısı*100 formülü ile hesaplanmıştır.

-Civciv kalitesi: Pas reform firması tarafından geliştirilen pasgar skor civciv kalite tespit yöntemi kullanılarak belirlenmiştir (Boerjan, 2006).

-Malformasyon ve Malpozisyon: Kabuk altı embriyo ölümleri olan yumurtalar incelenerek malformasyon ve malpozisyon oranları belirlenmiştir.

Kuluçkalık yumurtalarda hiçbir dezenfektan kullanılmadan önce, yumurtalar klorid grubu (kontrol grubu) ve \% 3, \% 6 ve \% 9 propolis içeren solüsyonla dezenfekte edildikten sonra alınan numuneler kuruduktan sonra ve kuluçkanın 18. gününde olmak üzere sürüntü yöntemiyle örnekler alınmış ve toplam bakteri sayıları tespit edilmiştir. Yumurtalar kuluçka makinelerine koyulmadan konulmadan önce dezenfekte yapılmadan, klorid grubu (kontrol grubu) ile \% 3, \% 6 ve \% 9 propolis içeren solüsyonlara daldırılıp kurutulduktan sonra bakteri sayımı için Mikrobiyoloji Laboratuvarına götürülmüștür.

Laboratuvarda yumurta örneklerinden yayma yöntemiyle ekim yapılmıștır. Yumurta kabuklarından steril çubuklar aracılı̆̆ıyla alınan sürüntü örnekleri $0.1 \mathrm{ml}$ serum fizyolojik içerisinde $10^{-2}, 10^{-3}, 10^{-4}$ ve $10^{-5}$ sulandırma oranlarında sulandırılarak önceden hazırlanmış olan L-Lizin dekarboksilasyon besiyerlerine drigalski spatülü kullanılarak yayma yöntemi ile ekim yapılmıştır. Drigalski spatülü her ekimden önce alkol çözeltisine batırılmış ve spatül alevden geçirilerek alkol uzaklaştırılmıştır. Ekim yapılan besiyerleri inkübatöre yerleștirilerek 36 saat bekletilmiştir. Koloni sayımları 36. saatin sonunda yapılmıştır. Koloni sayıları hesaplanırken 15 den az ve 300 den fazla olan koloni sayıları dikkate 
alınmamıș, son zamanlarda yaygın olarak kullanılan ardışık iki seyreltiden yapılan ekim sonuçlarından hareketle ve ağırlıklı aritmetik ortalama ile hesaplama yapılmıştır.

$\mathrm{Bu}$ hesaplamada aşağıda belirtilen formül kullanılmıştır.

$\mathrm{N}=\mathrm{C} /[\mathrm{V}(\mathrm{n} 1+0,1 \mathrm{X} \mathrm{n} 2) \mathrm{X} \mathrm{d}]$ şeklindedir.

$\mathrm{N}=$ Gıda örneğinin $1 \mathrm{~g}$ ya da 1 ml'sindeki mikroorganizma sayısı,

$\mathrm{C}=$ Sayımı yapılan tüm petri kutularındaki koloni sayısı toplamı,

$\mathrm{V}=$ Sayımı yapılan petri kutularına aktarılan hacim (ml),

n1= İlk seyreltiden yapılan sayımlarda sayım yapılan petri kutusu adedi,

n2= İkinci seyreltiden yapılan sayımlarda sayım yapılan petri kutusu adedi,

$\mathrm{d}$ = Sayımın yapıldığı ardışık 2 seyreltiden daha konsantre olanın seyreltme oranıdır.

Sayım sonucunda elde edilen sayı koloni oluşturan birim (kob-cob) / yumurta olarak verilmiştir.

Araştırmada elde edilen verilerin dağılım kontrolü Kolmogorov-Simirnov testi ile yapılmıştır. Varsayımları yerine getiren özelliklerin değerlendirilmesinde tek-yönlü varyans analizi (oneway ANOVA), farklı ortalamaların belirlenmesinde ise \% 5 önem düzeyinde yapılan Tukey Çoklu Karşılaştırma Testi, varyans analizinin varsayımlarını yerine getirmeyen özelliklerde Kruskal-Wallis testi kullanılmıştır. Verilerin analizi Minitab 16 programı ile yapılmıştır.

Çizelge 1. Kuluçka sonuçlarına ait bulgular

\begin{tabular}{|c|c|c|c|c|c|c|}
\hline Gruplar & $\begin{array}{c}\text { Döllülük Oranı } \\
\qquad \%)\end{array}$ & $\begin{array}{l}\text { Erken Dönem } \\
\text { Embriyo Ölüm } \\
\text { oranı (\%) }\end{array}$ & $\begin{array}{c}\text { Orta Dönem } \\
\text { Embriyo } \\
\text { Ölüm oranı } \\
(\%) \\
\end{array}$ & $\begin{array}{l}\text { Geç Dönem } \\
\text { Embriyo Ölüm } \\
\text { oranı (\%) }\end{array}$ & $\begin{array}{l}\text { Çıkış gücü } \\
(\%)\end{array}$ & $\begin{array}{c}\text { Kuluçka } \\
\text { Randımanı } \\
(\%)\end{array}$ \\
\hline & $\bar{X} \pm S_{\bar{x}}$ & $\bar{X} \pm S_{\bar{x}}$ & $\bar{X} \pm S_{\bar{x}}$ & $\bar{X} \pm S_{\bar{x}}$ & $\bar{X} \pm S_{\bar{x}}$ & $\bar{X} \pm S_{\bar{x}}$ \\
\hline Kontrol & $98.25 \pm 0.50$ & $5.57 \pm 0.95^{\mathrm{a}}$ & $1.27 \pm 0.57$ & $10.89 \pm 1.77^{b}$ & $81.95 \pm 1.04^{\mathrm{ab}}$ & $80.50 \pm 0.85^{\mathrm{ab}}$ \\
\hline \%3 Propolis & $98.50 \pm 0.46$ & $5.90 \pm 1.26^{\mathrm{ab}}$ & $1.03 \pm 0.48$ & $4.62 \pm 0.65^{\mathrm{a}}$ & $88.05 \pm 1.90 \mathrm{a}$ & $86.75 \pm 2.11^{\mathrm{a}}$ \\
\hline \%6 Propolis & $98.75 \pm 0.79$ & $11.43 \pm 1.76^{\mathrm{b}}$ & $0.26 \pm 0.26$ & $7.79 \pm 1.84^{\mathrm{ab}}$ & $80.76 \pm 2.14^{b}$ & $79.75 \pm 2.18^{b}$ \\
\hline \%9 Propolis & $98.50 \pm 0.73$ & $10.79 \pm 1.63^{\mathrm{ab}}$ & $1.32 \pm 0.59$ & $5.26 \pm 1.38^{\mathrm{ab}}$ & $83.25 \pm 0.94^{\mathrm{ab}}$ & $82.00 \pm 1.16^{\mathrm{ab}}$ \\
\hline $\mathrm{P}$ & 0.957 & $0.015^{*}$ & 0.423 & $0.035^{*}$ & $0.026^{*}$ & $0.040 *$ \\
\hline
\end{tabular}

a,b Farklı harfle gösterilen ortalamalar arasındaki farklılık önemlidir.

\section{Bulgular}

Araștırma da elde edilen verilerin değerlendirilmesi sonucunda kuluçka sonuçlarına ait bulgular Çizelge1'de, civciv kalitesi, ıskarka civciv, malformasyon ve malpozisyon oranlarına ait bulgular Çizelge 2'de, civciv kalitesi ölçüm metodu olan pasgar skor değerleri Çizelge 3'te verilmiştir. Döllülük oranı bakımından gruplar arasında farklılık bulunmamıștır $(\mathrm{P}>0.05)$. Döllülük oranı kuluçka özelliği olmayıp ancak kuluçkada tespit edilen bir özelliktir. Erken dönem embriyo ölüm oranı bakımından gruplar arasındaki farklılı̆̆ın önemli olduğu tespit edilmiştir $(\mathrm{P}<0.05) . \quad \mathrm{Bu}$ özellik bakımından kontrol grubunda, \% 6 propolis grubundan daha düşük oranda erken dönem embriyo ölümü gerçekleşmiştir. Diğer gruplar arasındaki farklılı̆̆ın önemsiz olduğu belirlenmiştir. Orta dönem embriyo ölüm oranı bakımından araştırma grupları arasında farklılık bulunmadığı tespit edilmiştir ( $\mathrm{P}>0.05)$. Geç dönem embriyo ölüm oranı bakımından gruplar arasındaki farklılığın önemli olduğu tespit edilmiştir $(\mathrm{P}<0.05)$. Bu özellik bakımından kontrol grubunda, $\% 3$ propolis grubundan daha yüksek oranda geç dönem embriyo ölümü gerçekleşmiştir. Diğer gruplar arasındaki farklılığın önemsiz olduğu belirlenmiștir. Çıkış gücü bakımından gruplar arasındaki farklılığın önemli olduğu belirlenmiștir $(\mathrm{P}<0.05)$. Gruplar arasında en yüksek çıkss gücü $\% \quad 3$ propolis grubunda gerçekleşirken en düşük çıkıș gücü ise $\% 6$ propolis grubunda olmuştur. 
Çizelge 2. Iskarka civciv, malpozisyon ve malformasyon oranlarına ait bulgular

\begin{tabular}{cccc}
\hline \multirow{2}{*}{ Gruplar } & $\begin{array}{c}\text { Iskarta } \\
\text { Civciv (\%) }\end{array}$ & $\begin{array}{c}\text { Malpozisyon } \\
(\%)\end{array}$ & $\begin{array}{c}\text { Malformasyon } \\
(\%)\end{array}$ \\
\cline { 2 - 4 } & $\bar{X} \pm S_{\bar{x}}$ & $\bar{X} \pm S_{\bar{x}}$ & $\bar{X} \pm S_{\bar{x}}$ \\
\hline Kontrol & $0.25 \pm 0.25$ & $7.37 \pm 1.51^{\mathrm{b}}$ & $0.76 \pm 0.51$ \\
\%3 Propolis & $0.51 \pm 0.31$ & $3.56 \pm 0.49^{\mathrm{ab}}$ & $0.00 \pm 0.00$ \\
\%6 Propolis & $0.26 \pm 0.26$ & $4.78 \pm 1.26^{\mathrm{ab}}$ & $1.52 \pm 0.47$ \\
\%9 Propolis & $0.00 \pm 0.00$ & $2.78 \pm 0.91^{\mathrm{a}}$ & $0.51 \pm 0.51$ \\
\hline P & 0.532 & $0.049^{*}$ & 0.130 \\
\hline $\begin{array}{c}\text { a,b Farklı harfle } \\
\text { önemlidir. }\end{array}$ & & &
\end{tabular}

Çizelge 3. Pasgar skor civciv kalite değerlerine ait bulgular

\begin{tabular}{cccc}
\hline Gruplar & Median & Ave Rank & $\mathrm{Z}$ \\
\hline Kontrol & 9.00 & 65.5 & 0.91 \\
\%3 Propolis & 9.00 & 59.9 & -0.12 \\
\%6 Propolis & 9.00 & 55.5 & -0.92 \\
\%9 Propolis & 9.00 & 61.2 & 0.12 \\
\hline P & 0.735 & - & - \\
\hline
\end{tabular}

Kuluçka randımanı bakımından gruplar arasında önemli farklılık olduğu tespit edilmiştir $(\mathrm{P}<0.05)$. Araştırmada ele alınan gruplar arasında en yüksek kuluçka randımanı $\% \quad 3$ propolis grubunda gerçekleşirken en düşük kuluçka randımanı ise \% 6 propolis grubunda olmuştur. Diğer gruplar arasında farklılık bulunmadığı belirlenmiştir. Iskarta civciv oranı bakımından araştırma grupları arasında farklılık bulunmadığı tespit edilmiştir ( $\mathrm{P}>0.05)$.

Malpozisyon oranı bakımından gruplar arasında önemli farklılık olduğu belirlenmiştir $(\mathrm{P}<0.05)$. En düşük malpozisyon oranı \% 9 propolis grubunda gerçekleşirken en yüksek malposizyon oranı ise kontrol grubunda olmuştur. Malformasyon oranı bakımından araştırma grupları arasında farklılık bulunmadığı tespit edilmiştir ( $\mathrm{P}>0.05)$.

Civciv kalitesi bakımından dezenfektan grupları arasında farklılı bulunmamıştır $(\mathrm{P}>0.05)$. Araştırma, Pasgar skor civciv kalite belirleme yöntemine göre yapılan değerlendirmede kontrol grubu dezenfektanı ile \% 3, \% 6 ve \% 9 oranlarda kullanılan propolisin civciv kalitesi üzerine benzer etkide bulunduğu tespit edilmiștir.

Dezenfektan gruplarının toplam bakteri sayısına ait bulgular Çizelge 4'de verilmiştir. Toplam bakteri sayısına etkinliği bakımından dezenfektan grupları arasında önemli bir farklılık bulunmamıștır $(P>0.05)$. Dezenfektanların etkinliğinin belirlenmesi amaciyla uygulama öncesi ile uygulama sonrası ve 18. gün toplam bakteri sayıları bakımından farklılı̆̆ın önemli olduğu belirlenmiștir $(\mathrm{P}<0.01)$.

Çizelge 4. Dezenfektan gruplarının uygulamalara göre toplam bakteri sayıları

\begin{tabular}{|c|c|c|c|c|}
\hline Gruplar/Uygulama & Kontrol grubu & $\% 3$ propolis & $\% 6$ propolis & $\% 9$ propolis \\
\hline Uygulama öncesi toplam bakteri sayısı* & $176.70 \times 10^{3} \mathrm{a}$ & $176.70 \times 10^{3} \mathrm{a}$ & $176.70 \times 10^{3} \mathrm{a}$ & $176.70 \times 10^{3} \mathrm{a}$ \\
\hline Uygulama sonrası toplam bakteri sayısı* & $48.00 \times 10^{3} \mathrm{~b}$ & $36.33 \times 10^{3} \mathrm{~b}$ & $52.67 \times 10^{3} \mathrm{~b}$ & $37.67 \times 10^{3 \mathrm{~b}}$ \\
\hline İnkübasyonun 18.günündeki toplam bakteri sayısı* & $93.00 \times 10^{3} \mathrm{~b}$ & $104.30 \times 10^{3} \mathrm{ab}$ & $76.00 \times 10^{3 \mathrm{~b}}$ & $76.30 \times 10^{3} \mathrm{~b}$ \\
\hline
\end{tabular}

"kob: koloni olușturan birim, a,b Farklı harfle gösterilen ortalamalar arasındaki farklılık önemlidir.

\section{Tartışma ve Sonuç}

Araştırmadan elde edilen sonuçlara göre döllülük oranı bakımından gruplar arasında farklılık bulunmadığı tespit edilmiş olup, bu durum gruplarda kullanılan kuluçkalık yumurtaların benzer döllülük oranına sahip olduğunu göstermektedir. Dezenfektan gruplarının erken dönem embriyo ölümleri üzerine etkisinin bulunduğu görülmektedir. Bu etki \%6 propolis grubunda kontrol grubuna göre daha fazla erken dönem embriyo ölümleri oluşturmak suretiyle kendini göstermiştir. Diğer propolis grupları ile kontrol grubu arasından benzer düzeyde erken dönem embriyo ölümleri görülmüştür. Araştırmada, \%6 propolis grubunda erken dönem embriyo ölümlerinin diğer gruplardan fazla olmasının nedeni belirlenememekle birlikte bu duruma, yumurta yüzeyinin propolis ile kaplanması neticesinde porlardan hava alışverişinin azalmasının yol açabileceği düşünülmektedir. Net olarak bir değerlendirme yapılabilmesi için konunun detaylı bir şekilde araştırılmasına ihtiyaç duyulmaktadır.

Orta dönem embriyo ölümleri bakımından dezenfektan grupları benzer bir etkiye sahip olmuşlardır. $\mathrm{Bu}$ özellik üzerine araştırmada kullanılan dezenfektanların etkisi istatistiki olarak farksız bulunmuştur ancak \%3 propolis grubunda rakamsal düzeyde görülen düşük orta dönem embriyo ölümü oranı çıkış gücünün bu grupta daha yüksek olması yönünde katkıda bulunduğu görülmektedir. 
Geç dönem embriyo ölümleri en düşük düzeyde \% 3 propolis ile dezenfekte edilen yumurtalarda görülmüştür. $\mathrm{Bu}$ özellik bakımından propolis grupları arasında istatistik farklılık bulunmamış olup, kontrol grubunda \% 3 propolis grubuna göre daha fazla geç dönem embriyo ölümü gerçekleşmiştir. $\mathrm{Bu}$ duruma kontrol grubunda bulunan yumurtalardaki embriyolarda daha fazla miktarda pozisyon bozukluğu olmasının neden olduğu sanılmaktadır. Orta dönem embriyo ölümlerinde olduğu gibi \% 3 propolis grubunda geç dönem embriyo ölümleri rakamsal olarak diğer gruplardan daha düşük olmuş ve bu durum \% 3 propolis grubunda çlkış gücünün yükselmesine olumlu etki yapmıştır.

Çıkış gücü \% 3 propolis grubunda $\% 6$ propolis grubundan yüksek bulunmuştur. Diğer gruplar bu özellik bakımından benzer özellik göstermiştir. Aynı durum kuluçka randımanında da ortaya çıkmıştır. Çıkış gücü ve kuluçka randımanı bakımından \%6 propolis ile dezenfekte edilen yumurtaların diğerlerinden daha düşük seviyede olduğu görülmektedir. Bu grupta çıkış gücü ve kuluçka randımanın düșük olması erken dönem embriyo ölümlerinin fazla olmasından kaynaklanmış olabileceği düşünülmektedir.. Diğer gruplar arasında istatistik olarak farklılık bulunmamakla birlikte \% 3 propolis ile dezenfekte edilen yumurtalarda bu özellikler bakımından bir üstünlük görülmekte ancak bunun teyit edilmesi için daha fazla araștırma yapılmasının gerekli olduğu düşünülmektedir.

Iskarta civciv oranı bakımından bütün dezenfektan grupları benzer etkide bulunmuşlardır. $\mathrm{Bu}$ özellik bakımından araştırmada kullanılan dezenfektan grupları arasında fark bulunmamaktadır. Yumurtalarda pozisyon bozukluğunu en düşük \%9 propolis grubunda en yüksek kontrol grubunda görülmüştür. Diğer gruplarda bulunan dezenfektanlar birbiriyle benzer etkide bulunmuştur. Malformasyon bakımından ise dezenfektanlar benzer etkide bulunmuş olup, kullanılan dezenfektanlardan bu özelliğin etkilenmediği görülmektedir.

Araştırmada civciv kalitesi pasgar skor kalite belirleme yöntemine göre yapılmıștır. Çıkıșı yapılan civcivlerin bütün dezenfektan gruplarında benzer kalitede olduğu görülmüştür. Elde edilen civciv kalite değeri kaliteli grubunda yer almıştır. Bu özellik üzerine kullanılan dezenfektanların olumsuz bir etkisinin bulunmadığı düşünülmektedir.
Dezenfektan uygulamasından önceki toplam bakteri sayısı, uygulama sonrasında önemli derecede düşüş göstermiştir. $\mathrm{Bu}$ bakımdan dezenfektanlar benzer etkiye sahip olmuşlardır. Ancak uygulama sonrası ve inkubasyonun 18. günündeki bakteri sayıları dikkate alındığında klorid grubu dezenfektan, \%6 propolis ve \% 9 propolis ile dezenfekte edilen yumurtalarda bakteri üremesi önemli bir seviyede görülmezken \% 3 propolisle dezenfekte edilen yumurtalarda bakteri üremesi fazla olmuş ve dezenfekte edilmeyen dönemdeki sayıya ulaşmıştır. Bu durum \%3 propolis ile dezenfeksiyonun etkinliğinin uzun süreli devam etmediğini göstermektedir.

Yıldız, (2006), yeterli hijyen kontrolü yapılmayan kuluçkahanelerde kuluçkalık yumurtaların E.Coli, Staphylococcus sp. ve Pseudomonas sp. gibi bakteriler ile kontamine olduklarını ve bunun sonucu olarak da göbek iltihabının görüldügünü bildirmiştir. Araștırma sonucunda elde edilen civcivlerde böyle bir sorunla karşılaşılmamıştır.

Aygün ve ark., (2012), kuluçkalık bıldırcın yumurtalarının benzalkoniyum klorür, $\% 70$ etil alkol ve $\% 5, \% 10$ ve $\% 15$ oranlarında propolis kullanılarak dezenfekte edilmesi ile kabuk yüzeyindeki mikrobiyal yükün propolis uygulanan gruplarda önemli ölçüde azaldığını, çıkış gücü, embriyonik ölüm oranları ve çıkım sonrası canlı ağırlık kazancı bakımından uygulamalar arasında farklılığın olmadığını belirtmiş olmalarına karşın, araştırmada propolis grupları arasında farklı sonuçlar elde edilmiştir. Araştırmalarda farklı sonuçlar bulunmasına materyal farklılığının neden olabileceği sanılmaktadır.

Aygün ve Sert, (2013), kuluçkalık bıldırcın yumurtalarını 7 ve 14 gün ön depolama işlemine maruz bırakılmış, ardından bu yumurtaları \% 70 etil alkol, \% 5, \% 10 ve \% 15 propolis ile dezenfekte ederek yaptıkları araştırmada propolisle spreylenmiş yumurtalarda toplam aerobik ve mezofolik bakterilerden koliform Salmonella spp., Staphylococcus spp. küf ve mayaların kontrol grubu ile \% 70’lik etil alkol uygulaması yapılmış gruplardan daha düşük olduğunu belirtmişlerdir. Çıkış gücü, embriyonik ölümler ve canlı ağırlık artışları üzerine propolisin farklı konsantrasyonlardaki uygulamalarında önemli farklılıklar tespit edilmediğini bildirmișlerdir.

Shahein ve Sedeek, (2014), damızlı tavuk yumurtalarını \% 7 ve \% 14 propolis, \% 0.5 ve 0.7 kekik uçucu yağı, \%70'lik etil alkol, formaldehit ve hiç dezenfekte edilmemiş gruplar oluşturarak kabuk 
yüzeyindeki mikrobiyal yükü belirlemek üzere yaptıkları araştırmada, gelişim dönemi ağırlık kaybının \% 14 propolis ile kekik uçucu yağ uygulanan gruplarda önemli derecede düşük olduğunu, en yüksek çıkış gücü ve civciv ağırlığının \% 14 propolis uygulanan gruptan elde edildiğini ve en düşük toplam embriyonik ölüm oranlarının ise \% 7 ve \% 14 propolis uygulanan gruplarda oluştuğunu bildirmişlerdir. Embriyo ölümleri bakımından araştırma sonuçları birbirini destekler nitelikte görülmemektedir. Bunda propolis oranları ve karşılaştırma yapılan diğer dezenfektanların farklı olmasının rolü önem arz etmektedir.

Kuluçkalık yumurtalarının gelişim makinelerine konulmasından önce dezenfekte edilmemesi durumunda, oluşabilecek bakteriyel bulaşmaya bağlı olarak kuluçka başarısının düşmesi, civciv kalitesinde ve civcivlerin büyüme performanslarında azalma ve mortalitede artma görülebileceği bildirilmiştir. (Scott ve Swetnam, 1993; Sacco ve ark. 1989; Reid ve ark. 1961).

Propolislerin antimikrobiyal etkileri farklı araştırmalarla belirlenmiştir. Kartal ve ark., (2003), Kazan ve Marmaris yörelerinden toplanan propolis örneklerinin etanolik özütlerinin gram pozitif (Staphylococcus aureus, Staphylococcus epidermidis, Enterococcus faecalis, Bacillus subtilis, Corynebacterium diphtheriae, Streptococcus pneumoniae ve Streptococcus pyogenes), gram negatif (Pseudomonas aeruginosa, E. coli, Klebsiella pneumoniae ve Branhamella catarrhalis) bakteriler ve mantarlar (Candida albicans) üzerine etkisini disk difüzyon yöntemi ile araştırmıştır. Kazan'dan izole edilen izomerik karışımın, S. aureus, S. epidermidis ve B. subtillis'e karşı etkili olduğu ve bu etkinin esas olarak kafeik asit esterleri nedeniyle ortaya çıktığ ifade etmişlerdir. Silici ve Kaftanoğlu, (2003), Türkiye'nin farklı yörelerinden (Bursa, İzmir, Kayseri, Sivas, Yozgat, Erzurum, Hatay ve Artvin) toplanmış olan propolis örneklerinin $S$. aureus ve $E$. coli bakterilerine karşı etkin antibakteriyel aktiviteye sahip olduğunu bildirmişlerdir. Bu sonuçlar propolisin potansiyel dezenfektan maddesi olduğunu açıklamaktadır. Kanatlı sektöründe dezenfektan maddesi olarak kullanılması konusunda değişik araştırmaların yapılarak yaygınlaştırılması yerinde olacaktır.

Günümüzde farklı kimyasal içerikleri olan birçok dezenfektan kuluçkalık yumurtaların dezenfeksiyonunda kullanılmaktadır. Formaldehit fumigasyonu, kuluçka işlemi öncesi yumurta kabuk yüzeyindeki mikrobiyal yükün azaltılmasında etkili bir antimikrobiyal temsilci olarak en yaygın kullanılan ancak aynı zamanda da en çok tartışılan yöntemlerden birisidir. Ancak formaldehidin toksik etkiye sahip olması nedeniyle insan sağlığına zarar vermesi nedeniyle insan sağlığına zarar vermeyen etkili bir dezenfektanın tespit edilmesi için araştırmalar devam etmektedir.

Sonuç olarak araştırmada kullanılan dezenfektanlardan \% 3 propolis grubunun diğer gruplara göre kuluçka özellikleri üzerine olumlu bir etkisinin olduğu görülmüştür. Ancak, etkisinin uzun süreli olmaması nedeniyle tekrar bakteri üremesi görülmesi olumsuz bir tablo ortaya çıarmaktadır. $\mathrm{Bu}$ yönünün iyileştirilmesi için değişik dezenfektanlarla birlikte kullanılması durumunda daha iyi sonuçlar verebileceği düşünülmektedir.

\section{Teşekkür}

Desteklerinden dolayı Ordu Üniversitesi Bilimsel Araștırma Projeleri Koordinatörlüğüne teşekkür ederiz (Proje no: BY-1702).

\section{Kaynaklar}

Anonim, 2017. Yumurta tavukçuluğu verileri. Yumurta Üreticileri Merkez Birliği. http://www.yumbir.org/UserFiles/File/Veriler2016.pdf (Erişim tarihi 24.02.2017)

Aygün, A., Sert, D., Çopur, G., 2012. Effects of propolis on eggshell microbial activity, hatchability, and chick performance in Japanese quail (Coturnix coturnix japonica) eggs. Poultry Science, 91 (10): 10181025.

Aygün, A., Sert, D., 2013. Effects of prestorage application of propolis and storage time on eggshell microbial activity, hatchability, and chick performance in Japanese quail (Coturnix coturnix japonica) eggs. Poultry Science, 92 (112): 3330-3337.

Baylan, M., Bulancak, A., Çopur Akpınar, G., Canoğulları, S., 2015. Kuluçkalık yumurtaların dezenfeksiyonunda kullanılan doğal ürünler. Çukurova Üniversitesi Ziraat Fakültesi Dergisi, 30: 25-32.

Benli, M., Yiğit, N., 2005. Ülkemizde yaygın kullanımı olan kekik (Thymus vulgaris) bitkisinin antimikrobiyal aktivitesi. Orlab On-Line Mikrobiyoloji Dergisi, 3(8): 1-8.

Boerjan, M., 2006. Chick vitality and uniformity. International Hatchery Practice, 20: 7-8.

Chute, H. L., Gershman, M., 1961. A new approach to hatchery sanitation, Poultry Science, 40: 468-571. 
Çadırcl, S., 2009. Disinfection of hatching eggs by formaldehyde fumigation - a review. Arch. Geflügelk., 73 (2): 116-123.

Dülger, B., Ceylan, M., Alitsaous M., Uğurlu E., 1999. Artemisia absinthium L. (Pelin)'un antimikrobiyal aktivitesi. Turkish Journal of Biology, 23 (3): 377384.

Elibol, O., 2014. Embriyo gelişimi ve kuluçka: Tavukçuluk Bilimi Yetiştirme, Besleme ve Hastalıklar, Editörler: Türkoğlu, M., Sarıca, M., Genişletilmiş 4. Baskı, Bey Ofset Matbaacllık, Ankara, s: 165-206.

Ernst, R. A., Bickford, A. A., Glick-Smith, J., 1980. Microbiological monitoring of hatcheries and hatching eggs. Poultry Science, 59: 1604.

Kartal, M., Yıldız, S., Kaya, S., Kurucu, S., Topçu, G., 2003 Antimicrobial activity of propolis samples from two different regions of anatolia. Journal of Ethnopharmacology, 86: 69-73.

Ledoux, L., 2004. The importance of hygiene and disinfection. International Hatchery Practice, 19: 11-15.

Reid, W.M., Maag, T.A., Boyd, F.M., Kleckner A.L., Schmittle, S.C., 1961. Embryo and baby chicks mortality and morbidity induced by a strain of Escherichia coli. Poultry Science, 40:1497-1502.

Sacco R.E., Renner, P.A., Nestor, K.E., Saif, Y.M., Dearth, R.N., 1989. Effect of hatching egg sanitizers on embryonic survival and hatchability of turkey eggs from different lines and on egg shell bacterial populations. Poultry Science, 68 (9):1179-1184.

Scott, T.A., Swetnam, C., 1993. Screening sanitizing agents and methods of application for hatching eggs. I. Environmental and User Friendliness. Journal of Applied Poultry Research, (2): 1-6.

Sheldon, B. W., Ball, J., 1986, Efficacy of ozon disinfection in poultry hatcheries. Industry Summary report 119, Southheastern poultry and egg association, Decatum. G.A.

Shahein, E.H.A., Sedeek E.K., 2014. Role of Spreying Hatching Eggs with natural disinfectants on hatching characteristics and eggshell bacterial counts. Egyptian Poultry Science Journal (34):213230 .

Silici, S., Kaftanoğlu O., 2003. Antimicrobial Analysis of propolis Samples From Differnt Regions in Turkey. Uludağ Bee Journal, August 2003: 16-18

Toroğlu, S., Çenet, M., 2006. Tedavi amaçlı kullanılan bazı bitkilerin kullanım alanları ve antimikrobiyal aktivitelerinin belirlenmesi için kullanılan metodlar. KSÜ. Fen ve Mühendislik Dergisi, 9 (2): 12-19.

Yıldız, T., 2006. Çeşitli dezenfektan maddelerin kuluçkalık yumurtaların dezenfeksiyonunda kullanım olanakları ve bunların bazı kuluçka özellikleri üzerindeki etkileri. Ziraat Mühendisliği Dergisi, 346: 48-52. 